\title{
Removal of fluoride from water by carbon nanotube supported alumina
}

\author{
Y. H. Li , S. Wang , X. Zhang , J. Wei , C. Xu , Z. Luan , D. Wu \& B. Wei
}

To cite this article: Y. H. Li , S. Wang , X. Zhang , J. Wei , C. Xu , Z. Luan , D. Wu \& B. Wei (2003) Removal of fluoride from water by carbon nanotube supported alumina, Environmental Technology, 24:3, 391-398

To link to this article: http://dx.doi.org/10.1080/09593330309385572

\section{曲 Published online: 17 Dec 2008.}

\section{Submit your article to this journal ¿}

Џlll Article views: 127

Q View related articles $\square$

Citing articles: 16 View citing articles $\square$ 


\title{
REMOVAL OF FLUORIDE FROM WATER BY CARBON NANOTUBE SUPPORTED ALUMINA
}

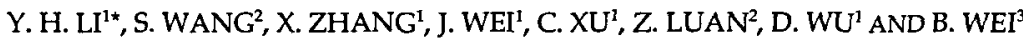

\author{
'Department of Mechanical Engineering, Tsinghua University, Beijing 100084, China \\ ${ }^{2}$ State Key Laboratory of Environmental Aquatic Chemistry, Research Center for Eco-Environmental Sciences, \\ Chinese Academy of Sciences, Beijing 100085, China \\ ${ }^{3}$ Department of Materials Science \& Engineering, Rensselaer Polytechnic Institute, Troy, NY 12180, USA
}

(Received 25 February 2002; Accepted 9 September 2002)

\begin{abstract}
This paper describes a new adsorption material, carbon nanotube supported alumina, used for fluoride removal from water. The effects of calcination temperature, alumina loading and $\mathrm{pH}$ on fluoride removal capacity were investigated. The optimum calcination temperature for preparing the adsorbents is $450^{\circ} \mathrm{C}$ and the largest adsorption capacity takes place at alumina loading of $30 \mathrm{wt} \%$. The broad $\mathrm{pH}$ range of $6.0-9.0$ with high adsorption capability suggests that carbon nanotube supported alumina have great potential applications in practice. The adsorption data at different $\mathrm{pH}$ were well fitted to the Freundlich isotherm. The kinetic studies show that the adsorption reaction of fluoride removal by carbon nanotube supported alumina can be described by a second order rate equation.
\end{abstract}

Keywords: Fluoride removal, adsorption, carbon nanotube supported alumina

\section{INTRODUCTION}

Wastewaters from semiconductor manufacturing, coal power plants, glass and ceramic production, uranium refinement and electroplating industries are enriched in fluoride and must be treated to achieve a suitable level of 0.5 $-1.0 \mathrm{mg} \mathrm{^{-1 }}$. Ingesting water with fluoride concentrations below this level will cause dental cavities while higher than this limit can lead to skeletal abnormalities, dental fluorosis, and kidney disease [1]. Many methods have been developed to remove the excess fluoride from wastewater: precipitation with calcium and aluminum salts [2,3], adsorption by activated alumina [4], alum, charcoal [5], ion exchange and membrane processes such as reverse osmosis nanofiltration [6], electrodialysis [7] and Donnan dialysis [8]. Of these methods, adsorption is the most widely used method and exploitation of more cost-effective adsorbents for fluoride removal has been the aim of researchers.

Carbon nanotubes (CNTs) are nanometer-size cylindrical tubules curled with concentric graphene sheets. They are arousing increasing interest in many potential applications, such as field emission [9], reinforcing materials [10] and nanodevices [11] due to their high mechanical property [12] and unique electrical property [13]. Their nanosize structure, large specific surface area, high thermal and chemical stabilities make CNTs ideal catalyst supporters or adsorbents. Planeix et al. first reported that in cinnamaldehyde hydrogenation Ru/CNTs had higher selectivity for cinnamyl alcohol (up to 92\%) than that of $\mathrm{Ru} / \mathrm{Al}_{2} \mathrm{O}_{3}$ catalyst (20-30\%) [14]. Che et al. deposited $\mathrm{Pt}$ and $\mathrm{Pt} / \mathrm{Ru}$ nanoparticles on CNT membranes and found that such catalyst-loaded membranes showed promising applications in electrocatalyzing $\mathrm{O}_{2}$ reduction and methanol oxidation, two reactions of importance to full cell technology [15]. Long and Yang reported that CNTs had a significantly higher dioxin removal efficiency than that of activated carbon [16]. Our previous studies suggested that $\mathrm{CNTs}$ and carbon nanotube supported alumina $\left(\mathrm{Al}_{2} \mathrm{O}_{3} / \mathrm{CNTs}\right)$ were good fluoride adsorbents and their fuoride removal capability were superior to activated carbon [17].

In this study, we examined the effects of calcination temperature, alumina loading and $\mathrm{pH}$ on fluoride removal capability of $\mathrm{Al}_{2} \mathrm{O}_{3} / \mathrm{CNTs}$. The kinetic model was used to describe the adsorption process and the mechanism of adsorption was investigated. These fundamental data will be useful for further studying the new adsorbent used in the 
treatment of wastewater containing fluoride.

\section{EXPERIMENTAL}

$\mathrm{Al}_{2} \mathrm{O}_{3} / \mathrm{CNT}$ s adsorbents were prepared by wetness impregnation of CNTs with appropriate amounts of aqueous solution of aluminum nitrate $\left(\mathrm{Al}\left(\mathrm{NO}_{3}\right)_{3} \cdot 9 \mathrm{H}_{2} \mathrm{O}\right)$. After drying at $100{ }^{\circ} \mathrm{C}$, the adsorbents were calcined for 2 hours at a temperature of $250-1050^{\circ} \mathrm{C}$ with an interval of $200^{\circ} \mathrm{C}$ under a stream of nitrogen.

The structure and morphology of the samples were studied by scanning electron microscope (SEM LEO-1350) and powdered X-ray diffraction (XRD D/max-RB). The surface area was determined using BET method (Micromeritics ASAP 2000).

Fluoride stock solution ( $593.1 \mathrm{mg} \mathrm{l}^{-1}$ ) was prepared by dissolving $\mathrm{NaF}$ in deionized water. The solution was further diluted to the required concentration before use.

The batch adsorption experiments were carried out in glass tubes at $25^{\circ} \mathrm{C}$ by putting weighted $\mathrm{Al}_{2} \mathrm{O}_{3} / \mathrm{CNTs}$ in 100 $\mathrm{ml} \mathrm{NaF}$ solution. The effect of heating temperature, different weight ratio and different $\mathrm{pH}$ values on fluoride adsorption was studied. In the experiment the initial $\mathrm{pH}$ values of the suspension were adjusted with $0.1 \mathrm{M} \mathrm{HNO}_{3}$ or $0.1 \mathrm{M} \mathrm{NaOH}$ solutions and the final $\mathrm{pH}$ values were recorded. The tubes were placed on a shaker (HZQ-C) and shaken for 6 hours and then the suspension was filtered through a $0.45 \mu \mathrm{m}$ membrane. The filtrate was measured by ion chromatography (4500i, U. S. A. DioneX Co.). The amount of fluoride adsorbed on the $\mathrm{Al}_{2} \mathrm{O}_{3} / \mathrm{CNTs}$ was determined as the difference between the initial concentration and the equilibrium concentration.

\section{RESULTS AND DISCUSSION}

Characterization of $\mathrm{Al}_{2} \mathrm{O}_{3} / \mathrm{CNT}$ s by SEM and XRD

Figure 1 shows the typical morphology of the $\mathrm{Al}_{2} \mathrm{O}_{3} / \mathrm{CNTs}$ materials. The $\mathrm{Al}_{2} \mathrm{O}_{3}$ and CNTs were mixed homogeneously and amalgamated into clumps. With increasing amounts of $\mathrm{Al}_{2} \mathrm{O}_{3}$, the CNTs in the SEM images decrease due to the covering role of $\mathrm{Al}_{2} \mathrm{O}_{3}$, while the morphologies of the $\mathrm{Al}_{2} \mathrm{O}_{3} / \mathrm{CNT}$ s prepared at different temperatures have no obvious difference in SEM images.

Five adsorbents prepared at different temperatures were characterized by $\mathrm{XRD}$. The diffraction patterns show that only at $1050^{\circ} \mathrm{C}$ are crystalline alumina $\left(\alpha-\mathrm{Al}_{2} \mathrm{O}_{3}\right)$ peaks, presents otherwise, the diffraction patterns are well indexed to crystalline CNTs and no peaks of crystalline alumina appear which suggest that alumina is in amorphous form.

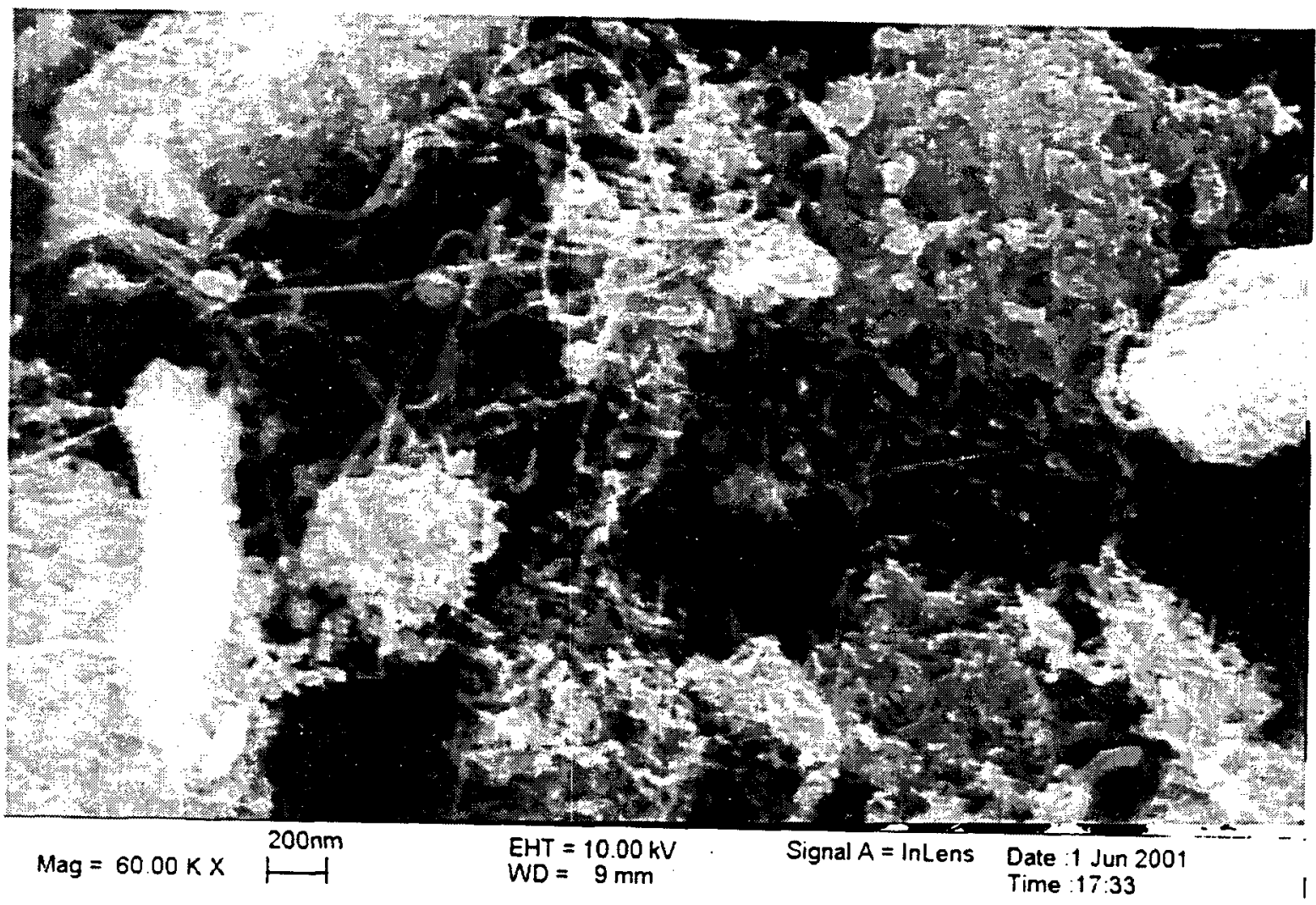

Figure 1. SEM image showing the morphology of $\mathrm{Al}_{2} \mathrm{O}_{3} / \mathrm{CNTs}\left(\mathrm{Al}_{2} \mathrm{O}_{3} 30 \mathrm{wt} \%, 450^{\circ} \mathrm{C}\right)$. 
Effect of Calcination Temperature

The effects of calcination temperature on the fluoride removal by $\mathrm{Al}_{2} \mathrm{O}_{3} / \mathrm{CNTs}$ were studied at $250,450,650,850$ and $1050^{\circ} \mathrm{C}$, respectively, using $0.5 \mathrm{mg} \mathrm{l}^{-1}$ of adsorbents and
$6 \mathrm{mg} \mathrm{l}^{-1}$ of fluoride ( $\mathrm{pH}=6.0$ ). The results show that the largest adsorption capacity of $9.6 \mathrm{mg} \mathrm{g}^{-1}$ for fluoride removal by $\mathrm{Al}_{2} \mathrm{O}_{3} / \mathrm{CNTs}$ is at the calcination temperature of about $450{ }^{\circ} \mathrm{C}$ (Figure 2a). Table 1 shows the porosity of pores as determined from nitrogen adsorption isotherms. The highest
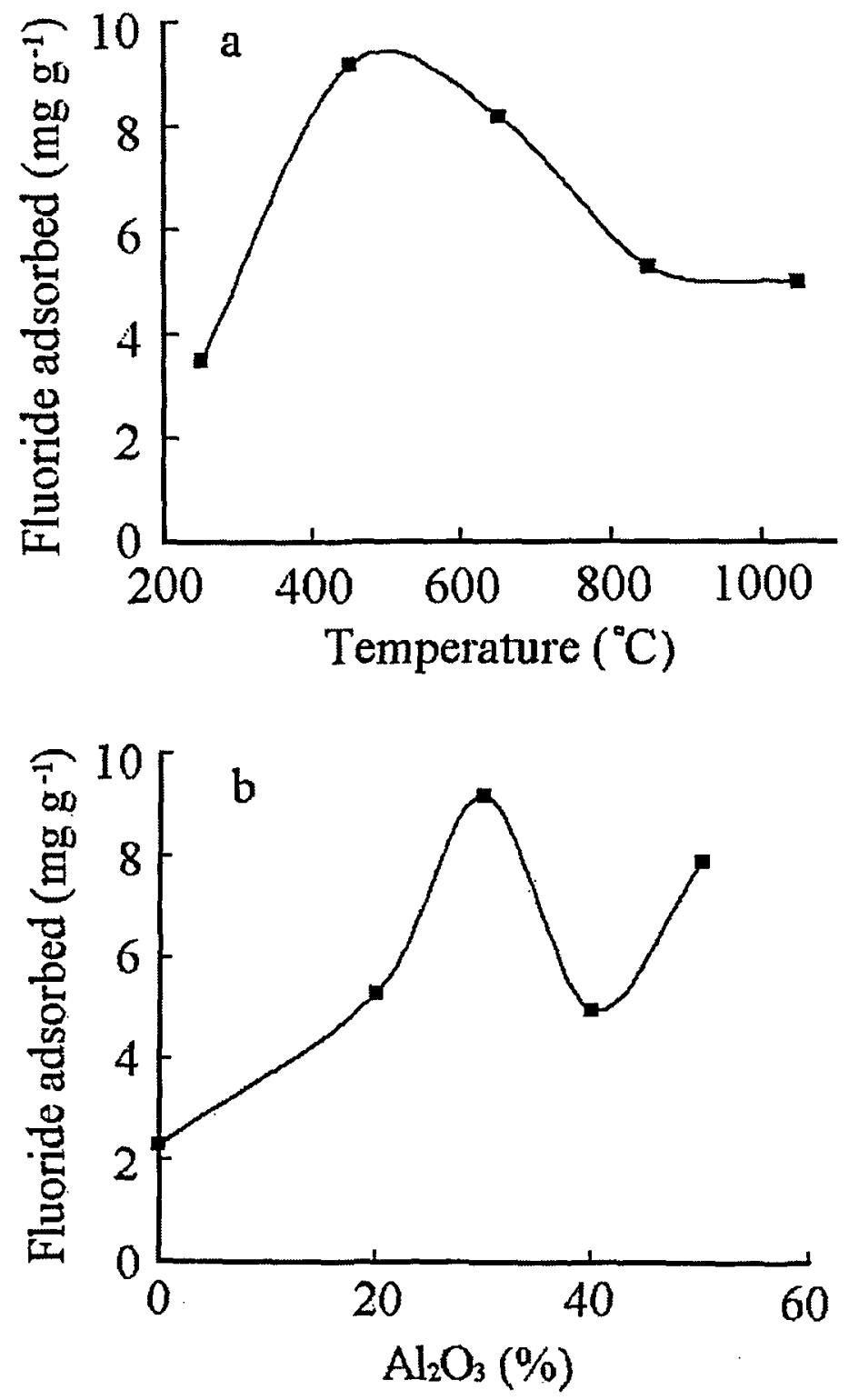

Figure 2. Effect of calcination temperature (a) and $\mathrm{Al}_{2} \mathrm{O}_{3}$ loading (b) on fluoride adsorbed onto the $\mathrm{Al}_{2} \mathrm{O}_{3} / \mathrm{CNTs}$.

Table 1. Porosity of $\mathrm{Al}_{2} \mathrm{O}_{3} / \mathrm{CNT}$ determined by nitrogen adsorption at different temperatures $\left(\mathrm{Al}_{2} \mathrm{O}_{3} 30 \mathrm{wt} \%\right)$.

\begin{tabular}{llllll}
\hline Calcination temperature $\left({ }^{\circ} \mathrm{C}\right)$ & 250 & 450 & 650 & 850 & 1050 \\
\hline Surface area $\left(\mathrm{m}^{2} \mathrm{~g}^{-1}\right)$ & 85 & 165 & 128 & 123 & 119 \\
Pore volume $\left(\mathrm{cm}^{3} \mathrm{~g}^{-1}\right)$ & 0.025 & 0.176 & 0.273 & 0.309 & 0.277 \\
Mean pore diameter $(\mathrm{nm})$ & 12.56 & 4.26 & 8.56 & 10.06 & 9.33 \\
\hline
\end{tabular}


specific area combining with the smallest size of the pores of $\mathrm{Al}_{2} \mathrm{O}_{3} / \mathrm{CNT}$ calcined at $450^{\circ} \mathrm{C}$ offers the largest adsorption capacity. The decrease in amount adsorbed at other temperatures may be due to the decline in dispersion force caused by increased pore-size and decreased specific surface area [18]. It is known that $\alpha-\mathrm{Al}_{2} \mathrm{O}_{3}$ has lower fluoride adsorption capacity. So the morphology of $\mathrm{Al}_{2} \mathrm{O}_{3}$ supported on CNTs changed from amorphous to $\alpha-\mathrm{Al}_{2} \mathrm{O}_{3}$ and is another reason for the drop in adsorption capacity of $\mathrm{Al}_{2} \mathrm{O}_{3} / \mathrm{CNTs}$ calcined at $1050^{\circ} \mathrm{C}$.

\section{Effect of $\mathrm{Al}_{2} \mathrm{O}_{3}$ Loading}

Five adsorbents differing in $\mathrm{Al}_{2} \mathrm{O}_{3}$ loading from 0 to 50 wt $\%$ were chosen to examine the effects of $\mathrm{Al}_{2} \mathrm{O}_{3}$ loading on the fluoride adsorption capacity $(\mathrm{pH}=6.0)$ and their porosities are shown in Table 2. The pure CNTs have the largest specific surface area and the smallest pore diameter and their fluoride adsorption capacity is $2.3 \mathrm{mg} \mathrm{g}^{-1}$. Figure $2 \mathrm{~b}$ shows that the adsorption capacity of adsorbents increases with increasing $\mathrm{Al}_{2} \mathrm{O}_{3}$ loading although the specific surface area decreases and reaches $9.6 \mathrm{mg} \mathrm{g}^{-1}$ at $\mathrm{Al}_{2} \mathrm{O}_{3}$ loading of $30 \mathrm{wt} \%$. The adsorption capacity descends to $5 \mathrm{mg} \mathrm{g}^{-1}$ at $\mathrm{Al}_{2} \mathrm{O}_{3}$ loading of $40 \mathrm{wt} \%$. When the $\mathrm{Al}_{2} \mathrm{O}_{3}$ loading attains 50 wt\%, the fluoride adsorption capacity rises again. However, $\mathrm{Al}_{2} \mathrm{O}_{3} / \mathrm{CNT}$ at this loading exists as a powder rather than clumps and is not practical to use.

\section{Effect of $\mathrm{pH}$}

The effect of different $\mathrm{pH}$ values of the solution on fluoride removal is shown in Figure 3. High adsorption capacity for fluoride removal was obtained for $\mathrm{Al}_{2} \mathrm{O}_{3} / \mathrm{CNTs}$ $\left(\mathrm{Al}_{2} \mathrm{O}_{3} 30 \mathrm{wt} \%\right.$, at $\left.25^{\circ} \mathrm{C}\right)$ in the $\mathrm{pH}$ range 6.0-9.0. However, at $\mathrm{pH}$ values $<6.0$ and $>9.0$, the fluoride adsorption capacity was found to decrease with decreasing $\mathrm{pH}$, and with increasing $\mathrm{pH}$, respectively.

Table 2. Porosity of $\mathrm{Al}_{2} \mathrm{O}_{3} / \mathrm{CNT}$ with different $\mathrm{Al}_{2} \mathrm{O}_{3}$ loading determined by nitrogen adsorption $\left(450^{\circ} \mathrm{C}\right)$.

\begin{tabular}{llllll}
\hline Percent of $\mathrm{Al}_{2} \mathrm{O}_{3}$ supported & 0 & $20 \%$ & $30 \%$ & $40 \%$ & $50 \%$ \\
\hline Surface area $\left(\mathrm{m}^{2} \mathrm{~g}^{-1}\right)$ & 178 & 164 & 165 & 125 & 97 \\
Pore volume $\left(\mathrm{cm}^{3} \mathrm{~g}^{-1}\right)$ & 0.406 & 0.177 & 0.176 & 0.202 & 0.223 \\
Mean pore diameter $(\mathrm{nm})$ & 3.9 & 4.31 & 4.26 & 6.46 & 5.05 \\
\hline
\end{tabular}

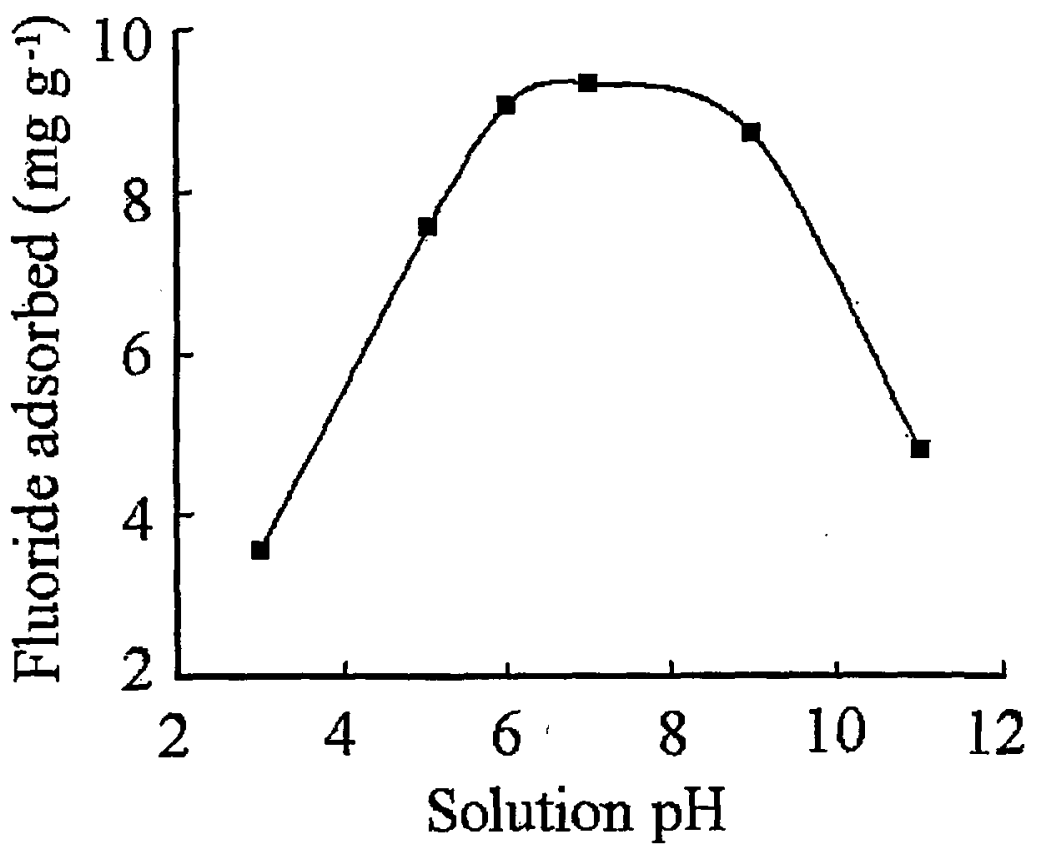

Figure 3. Amount of fluoride adsorbed onto the $\mathrm{Al}_{2} \mathrm{O}_{3} / \mathrm{CNTs}$ as a function of $\mathrm{pH}$ (calcination temperature $450^{\circ} \mathrm{C}, \mathrm{Al}_{2} \mathrm{O}_{3} 30$ wt $\%$, $\left.25^{\circ} \mathrm{C}\right)$. 
Adsorption Isotherms

The experimental data for fluoride removal by $\mathrm{Al}_{2} \mathrm{O}_{3} / \mathrm{CNTs}$ were adjusted using the Langmuir and Freundlich models whose linearized equations are, respectively:

$\frac{1}{q}=\frac{1}{q_{m}}+\frac{1}{b q_{m} C_{e}}$

$\ln q=\ln K_{F}+\frac{1}{n} \ln C_{c}$

where $C_{\mathrm{g}}$ is the equilibrium fluoride concentration $\left(\mathrm{mg} \mathrm{l}^{-1}\right), q$ is the amount adsorbed $\left(\mathrm{mg} \mathrm{g}^{-1}\right)$ and $\mathrm{q}_{\mathrm{m}}, \mathrm{b}, \mathrm{K}_{\mathrm{F}}$ and $\mathrm{n}$ are
Langmuir and Freundlich constants, respectively. The correlation coefficients $R^{2}$ (Table 3 ) were found to be $0.60-0.96$ for Langmuir model and 0.98-0.99 for Freundlich model, respectively. So the equilibrium adsorption data for different initial fluoride concentrations at different $\mathrm{pH}$ fit the Freundlich model better (Figure 4).

\section{Kinetics Studies}

The kinetics of fluoride adsorption were studied by varying the contact time from 1 to 530 minutes using $0.5 \mathrm{mg} \mathrm{l}^{-1}$ of $\mathrm{Al}_{2} \mathrm{O}_{3} / \mathrm{CNTs}$ at an initial fluoride concentration of $10.3 \mathrm{mg}$ $\mathrm{l}^{-1}$ (Figure 5a). It is evident that the curve obtained increases quickly during the first 75 minutes and about $50 \%$ of the fluoride was removed from water. Then the curve increases gradually. About $75 \%$ of fluoride is adsorbed from water when the equilibrium is reached after 20 hours.

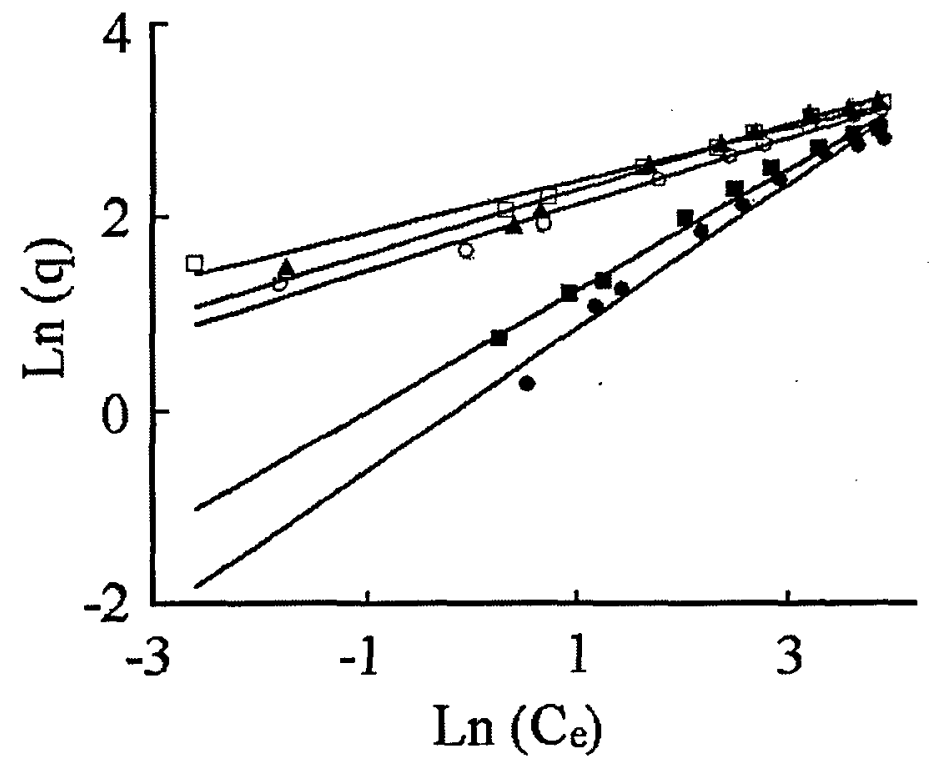

Figure 4. Linearized Freundlich isotherms for fluoride adsorption by the $\mathrm{Al}_{2} \mathrm{O}_{3} / \mathrm{CNTs}$ at different $\mathrm{pH}(\boldsymbol{\theta}, \mathrm{pH}=3.0 ; \boldsymbol{\Delta}, \mathrm{pH}=5.0$; $\square, \mathrm{pH}=7.0 ; 0, \mathrm{pH}=9.0 ; \mathbf{n}, \mathrm{pH}=11.0)$. $\left[\mathrm{Al}_{2} \mathrm{O}_{3} 30 \mathrm{wt} \%, 25^{\circ} \mathrm{C}\right]$.

Table 3. Langmuir and Freundlich isotherm constants.

\begin{tabular}{llllllll}
\hline \multirow{2}{*}{$\mathrm{pH}$} & \multicolumn{3}{c}{ Langmuir } & & \multicolumn{3}{c}{ Freundlich } \\
\cline { 2 - 3 } \cline { 6 - 8 } & $R^{2}$ & $q_{m}$ & $b$ & & $R^{2}$ & $K_{F}$ & $n$ \\
\hline 3.0 & 0.99 & 45.32 & 55.16 & & 0.98 & 1.13 & 1.33 \\
5.0 & 0.77 & 20.62 & 1.99 & & 0.98 & 8.24 & 3.71 \\
7.0 & 0.76 & 24.15 & 3.51 & & 0.98 & 7.06 & 2.99 \\
9.0 & 0.60 & 12.99 & 1.71 & & 0.99 & 6.01 & 2.93 \\
11.0 & 0.98 & 18.35 & 1.07 & & 0.99 & 1.86 & 1.59 \\
\hline
\end{tabular}



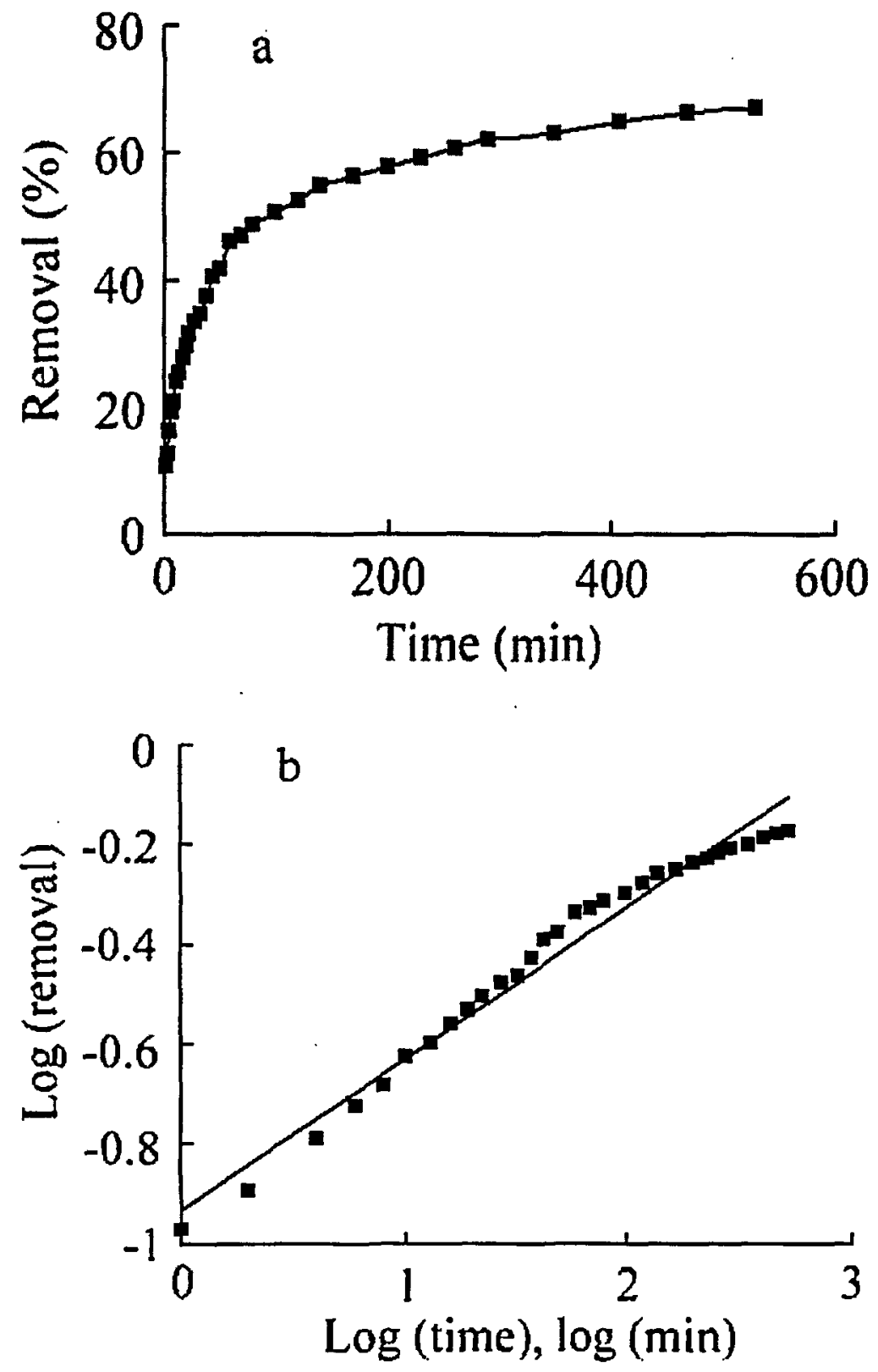

Figure 5. Kinetic study of fluoride adsorbed onto $\mathrm{Al}_{2} \mathrm{O}_{3} / \mathrm{CNT}$. a.) removal efficiency versus adsorption time; b.) logarithmic plot of removal efficiency versus time.

The following equation is applied to evaluate the adsorption kinetics [19]:

$R=k_{t} t^{m}$

(iii)

where $R$ is the fluoride removal efficiency $(\%), t$ is contact time and $k_{t}$ and $m$ are contants. A linear relationship between the $\log$ of percentage of fluoride removal versus the $\log$ of time is obtained with a regression coefficient of 0.975 (Figure
$5 b)$. The values of $m$ and $k_{t}$ are 0.323 and $0.117 \mathrm{~min}^{-m}$, respectively. The order of the reaction, $n$, is given by the following equation [19]:

$n=m^{-1}-1$

and a value of $2.09 n$ is calculated. Thus, it appears that the kinetics of fluoride removal by $\mathrm{Al}_{2} \mathrm{O}_{3} / \mathrm{CNTs}$ can be approximately represented by a second order rate equation. 
Adsorption Mechanism

It was reported that anion adsorption sites on alumina are aquo groups (-M-OH+2$)$ and hydroxo groups (-M-OH) [20]. Fluoride ions can be adsorbed by a positively charged surface and neutral surface through the following equations:

$-\mathrm{M}-\mathrm{OH}+\mathrm{HX} \leftrightarrow-\mathrm{M}-\mathrm{OH}_{2}^{+} \cdots \mathrm{X}^{-}$

$-\mathrm{M}^{-} \mathrm{OH}_{2}^{+} \cdots \mathrm{X}^{-}+\mathrm{F}^{-} \leftrightarrow-\mathrm{M}-\mathrm{F}+\mathrm{X}^{-}+\mathrm{H}_{2} \mathrm{O}$

$-\mathrm{M}-\mathrm{OH}+\mathrm{F}^{-} \leftrightarrow-\mathrm{M}-\mathrm{F}+\mathrm{OH}^{-}$

Equations (v) and (vi) take place at the positively charged surface and adsorbed $\mathrm{F}^{-}$through ligand exchange. When the surface is neutral, $\mathrm{F}^{-}$can be adsorbed by an ion exchange mechanism (equation (vii)). The isoelectric point (IEP) can be used to assess the adsorbent surface charge qualitatively. The IEP of $\mathrm{Al}_{2} \mathrm{O}_{3} / \mathrm{CNTs}$ is 7.5. In the region of $\mathrm{pH}<7.5$, the surface charge of $\mathrm{Al}_{2} \mathrm{O}_{3} / C N T s$ is positive, so adsorption of fluoride will abide by equations (v) and (vi). At $\mathrm{pH}=7.5$, the surface of $\mathrm{Al}_{2} \mathrm{O}_{3} / \mathrm{CNTs}$ is neutral and the reaction will take place according to equation (vii). By $\mathrm{pH}>7.5$, the hydroxo groups $(-\mathrm{M}-\mathrm{OH})$ will gradually disappear, at the same time, $\mathrm{OH}^{-}$will compete with fluoride ions for available sites left on the surface of the $\mathrm{Al}_{2} \mathrm{O}_{3} / \mathrm{CNTs}$ [20].

In addition, CNTs themselves are good fluoride adsorption materials [17] due to their large surface area and layered structure. The caps of CNTs can be opened up by means of ball milling and oxidation. The opened CNTs may not only transfer $\mathrm{F}^{-}$into the interior of the $\mathrm{Al}_{2} \mathrm{O}_{3} / \mathrm{CNTs}$ clumps, but also adsorb $\mathrm{F}^{-}\left(\mathrm{F}_{\text {radius }} 0.13 \mathrm{~nm}\right)$ on their outer surfaces, inner cavities and interlayers $(0.344 \mathrm{~nm})$. This could be the reason for high fluoride adsorption capacity $(4.8 \mathrm{mg} \mathrm{g}$ 1) of $\mathrm{Al}_{2} \mathrm{O}_{3} / \mathrm{CNT}$ even at $\mathrm{pH}=11.0$.

\section{CONCLUSIONS}

In summary, $\mathrm{Al}_{2} \mathrm{O}_{3} / \mathrm{CNT}$ could be used as a potential adsorbent for removal of fluoride from water. The optimum calcination temperature for fluoride removal by $\mathrm{Al}_{2} \mathrm{O}_{3} / \mathrm{CNTs}$ with the largest adsorption capacity of $9.6 \mathrm{mg} \mathrm{g}^{-1}$ is about 450 ${ }^{\circ} \mathrm{C}$, which attribute to their higher specific area and smaller pore size. With increasing $\mathrm{Al}_{2} \mathrm{O}_{3}$ loading, the highest adsorption capacity of $\mathrm{Al}_{2} \mathrm{O}_{3} / \mathrm{CNT}$ is reached at a loading of $30 \mathrm{wt} \%$. All adsorption isotherms at different $\mathrm{pH}$ are well fitted by the Freundlich equation. The optimal $\mathrm{pH}$ range of 6.0-9.0 for fluoride adsorption of $\mathrm{Al}_{2} \mathrm{O}_{3} / \mathrm{CNT}$ indicates that the new adsorbent has promising applications. Kinetic studies shows that fluoride adsorption by $\mathrm{Al}_{2} \mathrm{O}_{3} / \mathrm{CNTs}$ is a second order rate reaction.

\section{REFERENCES}

1. Lai Y.D. and Liu J.C., Fluoride removal from water with spent catalyst. Sep. Sci. Technol., 31, 2791-2803 (1996).

2. Saha S., Treatment of aqueous effluent for fluoride removal. Water Res., 27, 1347-1350 (1993).

3. Parthasarathy N., Buffle J. and Haerdi W., Combined use of calcium salts and polymeric aluminium hydroxide from defluoridation of waste waters. Water Res., 20, 443-448 (1986).

4. Lounici H., Addour L., Belhocine D., Grib H., Nicolas S., Bariou B. and Mameri N., Study of a new technique for fluoride removal from water. Desalination, 114, 241-251 (1997).

5. Bhargava D.S. and Killedar D.J., Fluoride adsorption on fishbone charcoal through a moving media adsorber. Water Res., 26, 781-788 (1992).

6. Simons R., Trace element removal from ash dam waters by nanofiltration and diffusion dialysis. Desalination, 89, 325-341 (1992).

7. Adhikary S.K., Tipnis U.K., Harkare W.P. and Govindan K.P., Defluoridation during desalination of brackish water by electrodialysis. Desalination, 71, 301-312 (1989).

8. Hichour M., Persin F., Sandeaux J. and Gavach C., Fluoride removal from waters by Donnan dialysis. Sep. Purif. Technol., 18, 1-11 (2000).

9. Rinzler A.G., Hafner J.H., Nikolaev P., Lou L., Kim S.G., Tomanek D., Nordlander P., Colbert D.T., and Smalley R.E., Unraveling nanotubes: Field emission from an atomic wire. Science, 269, 1550-1553 (1995).

10. Ajayan P. M., Stephan O., Collies C. and Trauth D., Aligned carbon nanotube arrays formed by cutting a polymer resinnanotube composite. Sci., 265, 1212-1214 (1994).

11. Collins P.G., Zettl A., Bando H., Thess A. and Smalley R.E., Nanotube nanodevice. Sci., 278, 100-103 (1997).

12. Treacy M.M., Ebbesen T.W. and Gibson J. M., Exceptionally high Young's modulus observed for individual carbon nanotubes. Nature, 381, 678-680 (1996).

13. Dai H., Wong E.W. and Lieber C.M., Probing electrical transport in nanomaterials: conductivity of individual carbon nanotubes. Sci., 272, 523-526 (1996). 
14. Planeix J.M., Coustel N., Coq B., Brotons V., Kumbhar P.S., Futartre R., Geneste P., Bernier P. and Ajayan P.M., Application of carbon nanotubes as supports in heterogeneous catalysis. J. Am. Chem. Soc., 116, 7935-7936 (1994).

15. Che G., Lakshmi B.B. and Fisher R.E., Carbon nanotube membranes for electrochemical energy storage and production. Nature, 393, 346-349 (1998).

16. Long R.Q. and Yang R.T., Carbon nanotubes as superior sorbent for dioxin removal. J. Am. Chem. Soc., 123, $2058-2059$ (2001).

17. Li Y.-H., Wang S., Cao A., Zhao D., Zhang X., Xu C., Luan Z., Ruan D., Liang J., Wu D. and Wei B., Adsorption of fluoride from water by amorphous alumina supported on carbon nanotubes. Chem. Phys. Lett., 350, 412-416 (2001).

18. Lalavni S.B., Wiltowski T., Hubner A., Weston A. and Mandich N., Removal of hexavalent chromium and metal cations by a selective and novel carbon adsorbent. Carbon, 36, 1219-1226 (1998).

19. Abe I., Fukuhara T., Maruyama J., Tatsumoto H. and Iwasaki S., Preparation of carbonaceous adsorbents for removal of chloroform from drinking water. Carbon, 39, 1069-1073 (2001).

20. Choi W.-W. and Chen K.Y., The removal of fluoride from wastes by adsorption. J. Am. Water Works Assoc., 71, 562-570 (1979). 